\title{
The effect of stock liquidity on the risk of falling stock prices: Evidence from the Tehran Stock Exchange
}

\author{
Mehdi Moghanloo $^{\mathrm{a}}$ and Hasan Madrakian ${ }^{\mathrm{b}}$
}

${ }^{a}$ Master's Degree student of Accounting, Department of Accounting and Management, South Tehran Branch, Islamic Azad University (IAU), Tehran, Iran

${ }^{b}$ Assistant Professor, Department of Accounting and Management, South Tehran Branch, Islamic Azad University (IAU), Tehran, Iran

\begin{tabular}{l}
\hline C H R O N I C L E \\
\hline Article history: \\
Received March 5, 2015 \\
Received in revised format \\
August 162015 \\
Accepted October 222015 \\
Available online \\
October 26 2015 \\
\hline Keywords: \\
Tehran Stock Exchange \\
Liquidity \\
Stock price
\end{tabular}
A B S T R A C T

\begin{abstract}
Liquidity of the stock exchanges plays essential role on investment decisions and it is one of the factors that may influence on stock price. The easier one can buy/sell shares of a firm, the higher liquidity the firm has. In fact, lack of liquidity may lead investors to sell their assets at cheaper prices and it could influence negatively on overall market. The primary objective of this paper is to study the effect of stock liquidity on the risk of falling stock prices. The study chooses historical information of 70 selected firms listed on Tehran Stock Exchange over the period 2006-2012. The results of this survey have indicated that there was a negative and meaningful relationship between stock liquidity and stock price decline.
\end{abstract}

(C) 2015 Growing Science Lid. All ights

\section{Introduction}

Liquidity of the stock exchanges plays essential role on investment decisions and it is one of the factors that influence on stock price. The easier one can buy/sell shares of a firm, the higher liquidity the firm has. In fact, lack of liquidity may lead investors to sell their assets at cheaper prices and it could influence negatively on overall market. The liquidity of stock shares, the relationship between volume of trading and changes in market price, has gained increasing recognition as an element of investment strategy. Pastor and Stambaugh (2001) studied whether market-wide liquidity was a state variable important for asset pricing. They reported that expected stock returns were associated with the sensitivities of returns to fluctuations in aggregate liquidity. Amihud and Mendelson (1986) investigated the impact of the bid-ask spread on asset pricing by analyzing a model in which investors with different expected holding periods trade assets with various relative spreads. Datar et al. (1998) examined Amihud and Mendelson's model using the turnover rate as a proxy for liquidity. They reported that liquidity plays essential role in describing the cross-sectional variation in stock returns.

\footnotetext{
* Corresponding author. Tel: +989194260131

E-mail address: m.moghanloo@outlook.cob (H. Madrakian) 
This effect insists after controlling for the determinants of stock returns such as firm-size, book-tomarket ratio and the firm beta. Unlike Eleswarapu and Reinganum (1993), they reported that the liquidity impact was not restricted to the month of January alone.

Cooper et al. (1985) investigated the relationship of common stock liquidity to both exchange listing and price behavior in the events of some major up/down movements in the market. They reported that liquidity was associated with price behavior; and recommended that exchange listing increases liquidity. In addition, they indicated that when the amount of company capitalization was taken into account, exchange listing would not necessarily yield bigger stock liquidity. Chordia et al. (2005) investigated cross-market liquidity dynamics by forecasting a vector autoregressive model for liquidity. In their survey, innovations to stock and bond market liquidity and volatility were substantially correlated, indicating that common factors could drive liquidity and volatility and volatility shocks gave insight on shifts in liquidity. Easley et al. (1998) studied the role of transactions volume in options markets by developing an asymmetric information model. They presented conditions under which informed traders trade options, and studied the implications of this for the linkage between markets.

\section{The proposed study}

The primary objective of this paper is to study the effect of stock liquidity on the risk of falling stock prices. The study chooses historical information of 70 selected firms listed on Tehran Stock Exchange over the period 2006-2012. There are five hypotheses associated with the proposed study as follows,

1. There is a significant relationship between stock liquidity and falling stock prices.

2. There is a significant relationship between stock liquidity and falling stock prices in the presence of the existing risk within the firm.

3. There is a significant relationship between stock liquidity and falling stock prices in the presence of the cost of research and development.

4. There is a significant relationship between stock liquidity and falling stock prices in the presence of ownership structure.

5. There is a significant relationship between stock liquidity and falling stock prices in the presence of institutional shareholders ratio.

\subsection{Independent variables}

RES $=$ The ratio of the closing price per share $\left(P_{i t}\right)$ on each trading day average share price during the year $\left(\sum \mathrm{p}_{\mathrm{it}}^{\mathrm{t}-1} /\right.$ dym $)$, where dym represents sum of trading days.

IP: This represents the lack of liquidity, which is calculated as follows,

$$
\mathrm{IP}=\text { average }\left(\left(\frac{\text { abs }(\text { daily return })}{\text { daily volume }}\right) \times 1000000\right)
$$

Zero $=$ The ratio of the number of days with zero return during the year as follows,

$$
\text { zero }=\frac{\sum \mathrm{zr}_{\mathrm{d}}}{\mathrm{dym}}
$$

where $\mathrm{zr}_{\mathrm{d}}$ represents the trading days with zero return.

PROV = The volatility of profits during the previous five years, which is calculated based on standard deviation of the profits on five years.

$\mathrm{R} \& \mathrm{D}=$ The ratio of $\mathrm{R} \& \mathrm{D}$ expenses divided by total assets. 
STIO = Institutional owners, that is, the proportion of institutional shareholders on total shareholders of the firm.

BLOCK = A dummy variable, which is one if there is at least one shareholder with minimum of 5\% ownership and zero, otherwise.

\subsection{Control variables}

SIGMA = The volatility of stock returns, which is the standard deviation of monthly stock returns during a given year.

RET $=$ The weighted average monthly returns of stocks over a year, which is calculated as follows,

$$
\operatorname{RET}_{\mathrm{i}, \mathrm{t}}=\frac{\text { start }_{\mathrm{i}, \mathrm{t}}-\mathrm{end}_{\mathrm{i}, \mathrm{t}}}{\text { start }_{\mathrm{i}, \mathrm{t}}}
$$

where start and end represent the start and end prices of shares, respectively.

DTURN $=$ The average stock turnover in the current year minus the average stock turnover last year and the average stock turnover is the ratio of the volume of transactions (number of shares traded during the year) to the total stock,

$$
\text { DTURN }=\frac{\text { Daily volume }}{\text { share }} .
$$

SIZE $=$ Represents the firm size, which is calculated by taking natural logarithm of total assets.

$\mathrm{MB}=$ The ratio of market value to book value.

$\mathrm{LEV}=$ Represents the leverage, which is calculated as a ratio of total liabilities on total assets.

$\mathrm{ROA}=$ Represent return on assets, which is calculated as the ratio of net earnings on total assets.

ACCM = Represents discretionary accruals, which is calculated as follows,

$$
\frac{\mathrm{ACC}}{\mathrm{TA}_{\mathrm{t}-1}}=\beta_{0} \frac{1}{\mathrm{TA}_{\mathrm{t}-1}}+\beta_{1} \frac{\Delta \text { sales }}{\mathrm{TA}_{\mathrm{t}-1}}+\beta_{2} \frac{\mathrm{PPE}}{\mathrm{TA}_{\mathrm{t}-1}}+\varepsilon_{\mathrm{i}, \mathrm{t}},
$$

where ACC represents the total accruals, which is calculated as net income before taxes minus cash flow from operating activities of firm $i$ in year $t$, TA, PPE and $\Delta$ sales are total assets, equipment and change in sales, respectively. Finally, $\varepsilon_{i, t}$ represents residuals. Eq. (1) to Eq. (5) represent the regression models to examine hypothesis one to five, respectively.

$$
\begin{aligned}
& \mathrm{CRASH}_{i, t}=\beta_{0}+\beta_{1} R E S_{i, t}+\beta_{2} \operatorname{SIGMA}_{i, t}+\beta_{3} \text { RET }_{i, t}+\beta_{4} \operatorname{DTURN}_{i, t}+\beta_{5} \operatorname{SIZE}_{i, t}+\beta_{6} M B_{i, t} \\
& +\beta_{7} L E V_{i, t}+\beta_{8} R O A_{i, t}+\beta_{9} A C C M_{i, t}+\varepsilon_{i t}, \\
& N S K E W_{i, t}=\beta_{0}+\beta_{1} R E S_{i, t}+\beta_{2} \text { SIGMA }_{i, t}+\beta_{3} P R O V+\beta_{4} R E T_{i, t}+\beta_{5} D T U R N_{i, t}+\beta_{6} \operatorname{SIZE}_{i, t} \\
& +\beta_{7} M B_{i, t}+\beta_{8} L E V_{i, t}+\beta_{9} R O A_{i, t}+\beta_{10} A C C M_{i, t}+\varepsilon_{i t}, \\
& N_{C R A S H} H_{i, t}=\beta_{0}+\beta_{1} I P_{i, t}+\beta_{2} \operatorname{SIGMA}_{i, t}+\beta_{3} R D+\beta_{4} R E T_{i, t}+\beta_{5} D_{T U} \operatorname{SRN}_{i, t}+\beta_{6} \operatorname{SIZE}_{i, t} \\
& +\beta_{7} M B_{i, t}+\beta_{8} L E V_{i, t}+\beta_{9} R O A_{i, t}+\beta_{10} A C C M_{i, t}+\varepsilon_{i t}, \\
& N S K E W_{i, t}=\beta_{0}+\beta_{1} I P_{i, t}+\beta_{2} S_{G I M A} A_{i, t}+\beta_{3} \text { BLOCK }_{i, t}+\beta_{4} R E T_{i, t}+\beta_{5} D_{T U R N} N_{i, t}+\beta_{6} \operatorname{SIZE}_{i, t} \\
& +\beta_{7} M B_{i, t}+\beta_{8} L E V_{i, t}+\beta_{9} R O A_{i, t}+\beta_{10} A C C M_{i, t}+\varepsilon_{i t}, \\
& \text { CRASH }_{i, t}=\beta_{0}+\beta_{1} Z_{E R O_{i, t}}+\beta_{2} \text { SIGMA }_{i, t}+\beta_{3} \text { STIO }_{i, t}+\beta_{4} R E T_{i, t}+\beta_{5} \text { DTURN }_{i, t}+\beta_{6} \text { SIZE }_{i, t} \\
& +\beta_{7} M B_{i, t}+\beta_{8} L E V_{i, t}+\beta_{9} R O A_{i, t}+\beta_{10} A C C M_{i, t}+\varepsilon_{i t},
\end{aligned}
$$


where NSKEW represents negative skewness of weekly returns during the year, which is a measure for falling stock prices.

\section{The results}

In this section, we present the implementation of the regression techniques on testing different hypotheses of the survey. Table 1 presents some basic statistics on the data used for the survey. As we can observe from the results, all statistics are within desirable levels.

Table 1

The summary of some basic statistics

\begin{tabular}{ccccccccc}
\hline Variable & Number & Mean & Median & Std. Dev. & Skewness & Kurtosis & Min & Max \\
\hline NSKEW & 525 & -0.74 & -0.78 & 1.15 & 0.31 & 0.09 & -3.45 & 2.6 \\
\hline RES & 525 & 1.01 & 0.99 & 0.24 & 1.08 & 3.16 & 0.41 & 2.17 \\
IP & 525 & 6.15 & 0.57 & 16.9 & 4.12 & 17.71 & 0 & 109.31 \\
\hline ZERO & 525 & 0.13 & 0.1 & 0.11 & 1.21 & 1.19 & 0 & 0.52 \\
\hline SIGMA & 525 & 10.28 & 9.37 & 5.6 & 1.28 & 2.85 & 0.1 & 38.3 \\
\hline RET & 525 & 2.41 & 2.11 & 4.04 & 0.85 & 2.24 & -7.94 & 23.13 \\
\hline DTURN & 525 & 0.01 & 0 & 0.23 & 0.4 & 7.51 & -1.17 & 1.19 \\
\hline SIZE & 525 & 13.12 & 13.02 & 1.48 & 0.69 & 0.64 & 9.91 & 18.29 \\
MB & 525 & 1.97 & 1.69 & 1.22 & 1.04 & 0.79 & 0.23 & 6.43 \\
\hline LEV & 525 & 0.06 & 0.04 & 0.07 & 2.87 & 9.76 & 0 & 0.45 \\
ROA & 525 & 0.14 & 0.13 & 0.11 & 0.74 & 0.99 & -0.13 & 0.55 \\
\hline ACCM & 525 & 0 & -0.01 & 0.92 & 0.11 & -0.56 & -2.26 & 2.24 \\
\hline STIO & 525 & 71.96 & 81.65 & 25.32 & -1.56 & 1.47 & 0 & 99.08 \\
\hline PROV & 525 & 90.709 & 22.14 & 20.26 & 73.71. & 14.52 & 11.16 & 128.28 \\
\hline R\&D & 525 & 0 & 0 & 0 & 4.73 & 24.49 & 0 & 0.02 \\
\hline BLOCK & 525 & 0.95 & 1 & 0.22 & -4.07 & 14.65 & 0 & 1 \\
\hline
\end{tabular}

Note that when dependent variable is dummy it is not possible to make normality assumption. Therefore we switch to logistic regression. In addition, the implementation of Kolmogorov-Smirnov on NSKEW yields $\mathrm{K}-\mathrm{S}=0.63$ (Sig. $=0.823$ ), which means the dependent variable is normally distributed. Moreover, our survey has indicated that there was not a strong correlation among independent variables.

\subsection{First hypothesis}

To examine the first hypothesis of the survey, we have used Chow method and realized that we should use pool method for regression model. Table 2 shows the results of the regression model. According to the results of Table 2, F-value is statistically significant, which means the relationship between dependent and independent variables is linear. Durbin-Watson value is within desirable level, which means there is no autocorrelation and finally, R-Square value is equal to 0.18 , which means the independent variables approximately predict $18 \%$ of the changes on dependent variable. The sign of RET is negative and meaningful, which means there was reverse relationship between dependent and independent variable and this confirms the first hypothesis of the survey. 
Table 2

The summary of regression model for the first hypothesis

\begin{tabular}{cccccc}
\hline Parameter & Coefficient & t-value & Sig. & Results & VIF \\
\hline Intercept & 1.345 & 6.78 & 0.000 & Positive and meaningful & - \\
\hline RES & -0.769 & -6.84 & 0.000 & Negative and meaningful & 2.68 \\
\hline SIGMA & -0.002 & -0.49 & 0.624 & Meaningless & 1.45 \\
\hline RET & 0.005 & 0.67 & 0.503 & Meaningless & 3.78 \\
\hline DTURN & 0.147 & 1.95 & 0.052 & Meaningless & 1.11 \\
\hline SIZE & 0.019 & 1.5 & 0.135 & Meaningless & 1.31 \\
MB & -0.018 & -1.05 & 0.294 & Meaningless & 1.6 \\
LEV & 0.07 & 0.29 & 0.773 & Meaningless & 1.03 \\
\hline ROA & -0.060 & 0.31 & 0.754 & Meaningless & 1.57 \\
\hline ACCM & 0.003 & 0.17 & 0.867 & Meaningless & 1.04 \\
\hline F-value $=12.18(0.000)$ & R-Square $=0.18$ & \multicolumn{2}{c}{ Durbin-Watson $=2.02$} & \\
\hline
\end{tabular}

\subsection{Second hypothesis}

To examine the second hypothesis of the survey, we have used Chow method and realized that we should use pool method for regression model. Table 3 presents the results of the regression model.

\section{Table 3}

The summary of regression model for the second hypothesis

\begin{tabular}{cccccc}
\hline Variable & Coefficient & t-value & P-value & Result & VIF \\
\hline Intercept & 1.057 & 1.55 & 0.122 & Positive and meaningful & - \\
RES & 0.123 & 0.4 & 0.692 & Meaningless & 1.03 \\
PROV & 0.0000014 & 4.11 & 0 & Positive and meaningful & 1.63 \\
\hline SIGMA & -0.016 & -1.55 & 0.121 & Meaningless & 4.37 \\
RET & -0.102 & -4.60 & 0 & Negative and meaningful & 1.64 \\
DTURN & 0.544 & 2.6 & 0.01 & Meaningless & 1.11 \\
SIZE & -0.130 & -2.62 & 0.009 & Negative and meaningful & 1.33 \\
MB & 0.039 & 0.78 & 0.437 & Meaningless & 0.58 \\
LEV & 0.295 & 0.44 & 0.661 & Meaningless & 1.03 \\
\hline ROA & -0.238 & -0.45 & 0.65 & Meaningless & 1.57 \\
ACCM & -0.016 & -0.32 & 0.748 & Meaningless & 1.04 \\
\hline
\end{tabular}

F-value $=10.63(0.000) \quad$ R-Square $=0.17 \quad$ Durbin-Watson $=1.94$

According to the results of Table 3, F-value is statistically significant, which indicates the relationship between dependent and independent variables is linear. Durbin-Watson value is within desirable level, which means there is no autocorrelation and finally, R-Square value is equal to 0.17 , which means the independent variables approximately predict $17 \%$ of the changes on dependent variable. The sign of RET is meaningless, which means there was not any meaningful relationship between dependent and independent variable in the presence of PROV and we cannot confirm the second hypothesis of the survey. 


\subsection{Third hypothesis}

To examine the third hypothesis of the survey, we have applied Chow method and realized that we should use pool method for regression model. Table 4 shows the results of the regression model.

\section{Table 4}

The summary of regression model for the third hypothesis

\begin{tabular}{cccccc}
\hline Variable & Coefficient & t-value & Sig. & Result & VIF \\
\hline Intercept & 0.568 & 3.26 & 0.001 & Positive and meaningful & - \\
IP & 0.001 & 0.52 & 0.603 & Meaningless & 1.03 \\
R\&D & -12.832 & -1.50 & 0.135 & Meaningless & 1.25 \\
SIGMA & 0.003 & 0.86 & 0.389 & Meaningless & 1.37 \\
RET & -0.03 & -6.20 & 0 & Negative and meaningful & 1.64 \\
DTURN & 0.12 & 1.51 & 0.132 & Meaningless & 1.11 \\
SIZE & 0.02 & 1.46 & 0.144 & Meaningless & 1.33 \\
MB & -0.007 & -0.41 & 0.684 & Meaningless & 1.58 \\
LEV & 0.099 & 0.39 & 0.698 & Meaningless & 1.03 \\
ROA & 0.054 & 0.27 & 0.788 & Meaningless & 1.57 \\
ACCM & 0.008 & 0.39 & 0.696 & Meaningless & 1.04 \\
\hline F-value $=5.69$ & $(0.000)$ & R-Square $=0.1$ & \multicolumn{2}{c}{ Durbin-Watson = 2.08 } & 0 \\
\hline \multicolumn{2}{r}{} & & & \multicolumn{2}{c}{}
\end{tabular}

According to the results of Table 4, F-value is statistically significant, which means the relationship between dependent and independent variables is linear. Durbin-Watson value is within desirable level, which means there is no autocorrelation and finally, R-Square value is equal to 0.10 , which indicates the independent variables approximately predict $10 \%$ of the changes on dependent variable. The sign of RET is meaningless, which means there was not any meaningful relationship between dependent and independent variable in the presence of $R \& D$ and we cannot confirm the third hypothesis of the survey.

\subsection{Fourth hypothesis}

To examine the fourth hypothesis of the survey, we have applied Chow method and understand that we need to use pool method for regression model. Table 5 shows the results of the regression model.

Table 5

The summary of regression model for the fourth hypothesis

\begin{tabular}{|c|c|c|c|c|c|}
\hline Variable & Coefficient & t-value & Sig. & Result & VIF \\
\hline Intercept & -0.868 & -1.79 & 0.075 & Meaningless & - \\
\hline IP & 0.011 & 3.82 & 0 & Positive and meaningful & 2.68 \\
\hline BLOCK & 0.12 & 0.57 & 0.569 & Meaningless & 1.7 \\
\hline SIGMA & -0.017 & -1.73 & 0.085 & Meaningless & 1.45 \\
\hline RET & -0.097 & -6.49 & 0 & Negative and meaningful & 3.78 \\
\hline DTURN & 0.431 & 2.06 & 0.04 & Positive and meaningful & 1.11 \\
\hline SIZE & 0.031 & 0.85 & 0.393 & Meaningless & 1.31 \\
\hline MB & -0.017 & -0.36 & 0.721 & Meaningless & 1.6 \\
\hline LEV & 0.075 & 0.11 & 0.911 & Meaningless & 1.03 \\
\hline ROA & -0.221 & -0.42 & 0.674 & Meaningless & 1.57 \\
\hline ACCM & -0.030 & -0.58 & 0.559 & Meaningless & 1.04 \\
\hline
\end{tabular}


According to the results of Table 5, F-value is statistically significant, which means the relationship between dependent and independent variables is linear. Durbin-Watson value is within desirable level, which means there is no autocorrelation and finally, R-Square value is equal to 0.17 , which indicates the independent variables approximately predict $17 \%$ of the changes on dependent variable. The sign of IP is meaningful, which means there is a positive and meaningful relationship between dependent and independent variable in the presence of BLOCK and we may confirm the fourth hypothesis of the survey.

\subsection{Fourth hypothesis}

To examine the last hypothesis of the survey, we have applied Chow method and realized that we should use pool method for regression model. Table 6 presents the results of the regression model.

\section{Table 6}

The summary of regression model for the fifth hypothesis

\begin{tabular}{|c|c|c|c|c|c|}
\hline Variable & Coefficient & t-value & Sig. & Result & VIF \\
\hline Intercept & 0.568 & 3.23 & 0.001 & Positive and meaningful & - \\
\hline ZERO & 0.059 & 0.33 & 0.743 & Meaningless & 1.03 \\
\hline STIO & -0.002 & -3.05 & 0.002 & Negative and meaningful & 1.13 \\
\hline SIGMA & 0.004 & 1.06 & 0.291 & Meaningless & 1.37 \\
\hline RET & -0.036 & -6.48 & 0 & Negative and meaningful & 1.64 \\
\hline DTURN & 0.112 & 1.43 & 0.154 & Meaningless & 1.11 \\
\hline SIZE & 0.03 & 2.14 & 0.032 & Positive and meaningful & 1.33 \\
\hline MB & -0.002 & -0.10 & 0.924 & Meaningless & 1.58 \\
\hline LEV & 0.143 & 0.57 & 0.569 & Meaningless & 1.03 \\
\hline ROA & 0.056 & 0.28 & 0.776 & Meaningless & 1.57 \\
\hline ACCM & 0.01 & 0.51 & 0.612 & Meaningless & 1.04 \\
\hline \multicolumn{2}{|c|}{ F-value $=6.85(0.000)$} & R-Square $=0.12$ & \multicolumn{2}{|c|}{ Durbin-Watson $=2.05$} & 0 \\
\hline
\end{tabular}

According to the results of Table 6, F-value is statistically significant, which means the relationship between dependent and independent variables is linear. Durbin-Watson value is within desirable level, which means there is no autocorrelation and finally, R-Square value is equal to 0.12 , which indicates the independent variables approximately predict $12 \%$ of the changes on dependent variable. The sign of Zero is meaningless, which means there was not any meaningful relationship between dependent and independent variable in the presence of STIO and we cannot confirm the fifth hypothesis of the survey.

\section{Conclusion}

Liquidity of the stock exchanges has played essential role on investment decisions and it is one of the factors that may have a strong effect on stock price. In fact, lack of liquidity may lead investors to sell their assets at cheaper prices and it could influence negatively on overall market. The primary objective of this paper was to study the effect of stock liquidity on the risk of falling stock prices. The study chose historical information of 70 selected companies listed on Tehran Stock Exchange from 2006 to 2012. The results of this survey have indicated that there was a negative and meaningful relationship between stock liquidity and stock price decline. In addition, there was a significant relationship between stock liquidity and falling stock prices in the presence of ownership structure. However, there was not any meaningful relationship between stock liquidity and falling stock prices in the presence of the existing risk within the firm, research and development and institutional shareholders ratio. 


\section{Acknowledgement}

The authors would like to thank the anonymous referees for constructive comments on earlier version of this paper.

\section{References}

Amihud, Y., \& Mendelson, H. (1986). Asset pricing and the bid-ask spread.Journal of financial Economics, 17(2), 223-249.

Chordia, T., Sarkar, A., \& Subrahmanyam, A. (2005). An empirical analysis of stock and bond market liquidity. Review of Financial Studies, 18(1), 85-129.

Cooper, S. K., Groth, J. C., \& Avera, W. E. (1985). Liquidity, exchange listing, and common stock performance. Journal of Economics and Business, 37(1), 19-33.

Datar, V. T., Naik, N. Y., \& Radcliffe, R. (1998). Liquidity and stock returns: An alternative test. Journal of Financial Markets, 1(2), 203-219.

Eleswarapu, V. R., \& Reinganum, M. R. (1993). The seasonal behavior of the liquidity premium in asset pricing. Journal of Financial Economics, 34(3), 373-386.

Easley, D., O'hara, M., \& Srinivas, P. S. (1998). Option volume and stock prices: Evidence on where informed traders trade. The Journal of Finance,53(2), 431-465.

Pastor, L., \& Stambaugh, R. F. (2001). Liquidity risk and expected stock returns (No. w8462). National Bureau of Economic Research. 